\title{
The Effects of Studying Abroad and Studying Sustainability on Students' Global Perspectives
}

\author{
Michael A. Tarrant \\ The University of Georgia \\ Donald L. Rubin \\ The University of Georgia \\ Lee Stoner \\ Massey University
}

\section{Introduction}

Study abroad has shifted from a marginal opportunity for higher education students to a core strategy of U.S. colleges and universities, considered integral in the mission to globalize the academic environment (Sutton, Miller \& Rubin, 2007). The assumption is that a broad set of efforts to expose students to alternate ways of viewing the world (including international education but also multicultural and sustainable education) nurtures a global awareness and world-mindedness (Merrill, Braskamp, \& Braskamp, 2012) though strong empirical support is lacking (McKeown, 2009; McLeod \& Wainwright, 2009; Sobania \& Braskamp, 2009; Streitwieser \& Light, 2010; Sutton \& Rubin, 2004).

\section{Purpose}

Our study explores the effect of short-term study abroad programs (some of which explicitly focused on sustainability) on higher education students' global perspectives. Specifically, do studying abroad and/or studying about sustainability promote cognitive, intrapersonal, and social development beyond that achieved via on-campus courses?

\section{Global Perspectives}

The call to develop curricula that foster a student citizenry with stronger global perspectives emanates from several camps. First, a growing consensus highlights the contribution of international education to the academic missions of higher education systems, as a means of globalizing the university environment (Childress, 2009; Hanson, 2010; Hovland, 2009; Lewin, 2009). In 2006, 40\% of universities and colleges included a reference to international education as part of their mission statement, up from 28\% in 2001 (Stearns, 2009). Such consensus reflects a general notion that intellectual and personal development is greater among students who study abroad than for those who do not (National Survey of Student Engagement, 2007). Accordingly, Braskamp, Braskamp, and Merrill (2009) propose "student engagement in education abroad experiences enhances global learning and development, which we argue should now become an important and even the core of holistic student development, a goal of almost every undergraduate college or university" (p.111).

Second, international education contributes to the pragmatic value of a college degree. The Association of American Colleges and Universities (2007), for example, recognizes the value of a global perspective in enhancing the employment prospects for graduates. In a similar vein, authorities acknowledge the social and economic importance of promoting global mindedness among future generations (Norris \& Gillespie, 2009). Various studies of the impact of studying abroad on alumni career and avocational choices support the conclusion that such experiences encourage participants 
to enter careers in advanced professions, pursue work or volunteer experience in international settings, and tend to increase earning power (Dwyer, 2004a; Franklin, 2010; Paige, Fry, Stallman, Jon, \& Josić, 2010).

Finally, a political rationale for international education, including study abroad, is founded on the need for improved national security (Commission on the Abraham Lincoln Study Abroad Fellowship Program, 2005; Durbin, 2006; Government Accountability Office, 2007). Senator Richard J. Durbin, for example, argued "it is the responsibility of the American educational system to engage students in global education" (2006, p.6). Similarly, the bi-partisan Lincoln Commission reported, "Our national security and domestic prosperity depend upon a citizenry that understands America's place in the world, the security challenges it faces, and the opportunities and perils confronting Americans around the world. Responding to these realities requires a massive increase in the global literacy of the typical college graduate" (2005, ix). Thus there has been unprecedented impetus and growth over the past decade in international education as a vehicle to educate students as citizens for a truly globalized world (AACU, 2012).

The outcomes of such education might include knowledge of historical and political factors that determine the relations between one's own nation and other nations, capacity to communicate in world languages, willingness to engage in solving global problems, and capacity to engage in dialogue with others of differing backgrounds and beliefs (Musil, 2006). What has been too often lacking, however, is more stringent empirical evidence that documents the substantive effects of study abroad on such broader global learning outcomes, beyond that obtained through traditional on-campus courses (Sutton, et al., 2007).

\section{Global Perspectives Inventory (GPI)}

In recent years, the Global Perspectives Inventory (GPI) has been one of the most widely adopted measures to assess student learning from international learning initiatives in general (e.g., Engberg \& Fox 2011) and from study abroad in particular (Braskamp, et al., 2009). The GPI has been administered to approximately 80,000 undergraduate students across more than 140 public and private four-year universities and colleges to assess student learning and development (Braskamp \& Braskamp, 2013; Braskamp \& Engberg, 2011; Braskamp, Braskamp, \& Engberg, 2013). The scale assesses three domains deemed central to the growth and development of college-aged (18-24 year old) students: How do I know? Who am I? and How do I relate to others? These questions are addressed through a bank of self-reported items reflecting three corresponding domains (with two scales in each domain): cognitive, intrapersonal, and interpersonal. The cognitive domain focuses on knowledge (the level of understanding and awareness of other cultures) and knowing (how does one acquire knowledge, and evaluate what is important to know, about other cultures). The intrapersonal domain is comprised of identity (the level of self-awareness and acceptance of their own culture) and affect (the degree of respect for, and acceptance of, other cultures). The interpersonal domain reflects social responsibility (the level of concern for, and interdependence with, others) and social interactions (the amount of involvement with, and cultural sensitivity to, others). Test-retest reliabilities (correlations) and internal consistency (alpha) of the six scales have proved to be acceptable, ranging from .49 to .81 and from .63 to .75 , respectively (Braskamp, et al., 2013).

While the most common application of the GPI has been in traditional campus-based courses, 
the GPI has also been administered to illuminate how study abroad programs may influence students' global perspectives. For example, Braskamp, et al. (2009) found higher posttest (compared with pretest) scores across most items in the GPI for 245 students who had participated in ten different semester-long education abroad programs from five different universities. Their study, however, neither included a control group (i.e., raising concerns over how corresponding non-study students might have performed over the same duration) nor a statistical significance test (rather, an arbitrary difference of .10 in pretest versus posttest mean values was deemed sufficient to warrant a "significance"). In other work, Braskamp, et al. (2013) have reported positive changes (from prestest to posttest measures) in global perspectives of between .03 and .33 , but again neither control groups nor rigorous statistical tests were applied.

\section{Global Perspectives and Sustainability}

The framework of sustainability provides a platform by which to understand and promote students' global perspectives. At its core, sustainability addresses issues of intra- and inter-personal equity in order to meet present and future needs (World Commission on Environment and Development, 1987). However, its relation with global perspectives is most clearly evident through the range of actions commonly associated with sustainability: Green economics, cultural and civic engagement and responsibility, ecological conscience, and good governance, known collectively as the quadruple bottom line, an extension of the original triple bottom line of people, planet, and profit (Elkington, 1998). Sustainability is therefore more expansive than the traditional concept of environmentalism (a.k.a. conservation and preservation); it envisions a global citizenry with a worldview that critically evaluates personal and social standing. The core questions that provide the basis for the GPI likewise provide a platform for understanding and relating to the goals of sustainability. Accordingly, we propose that academic courses emphasizing sustainability may be the ones most likely to promote global perspectives (see also Tarrant, 2010).

Sustainability bears on issues of social equity that are central to notions of global citizenship and interdependence and, as such, offers a logical academic context for nurturing global learning outcomes. The AACU (2007) also recognizes that ensuring global sustainability is one of "[T] he major issues and problems of our time... [and] transcends individual disciplines" (p. 20). In accord with a recent national call to action (The National Task Force on Civic Learning and Democratic Engagement, 2012) it has been suggested that overseas courses in sustainability can promote cognitive development (ways of knowing and understanding what is true) and intrapersonal skills (forming a level of respect for and acceptance of others). Both of these dimensions are recognized as being necessary in advancing a platform of civic learning and democratic engagement in a global society.

Encouraging university students to grapple with, reframe, and reflect on issues of sustainability will, arguably, exert impact on young people's life direction, their self-identity, and their relationship to broader social and cultural values and ethics. Tarrant, et al. (2013) have demonstrated that, when carefully crafted, overseas outbound educational travel programs have the potential to produce significant increases in attitudes toward global citizenship (as measured by self-reported scores on three measures: ecological conscious consumer behaviors, support for environmental policies, and environmental citizenship). In a second study examining the same student outcomes, course subject matter (sustainability versus non-sustainability) interacted with course location (study abroad versus on-campus study), with the greatest (positive) effect on global citizenry occurring in the presence of 
sustainability courses offered abroad (Tarrant, Rubin, \& Stoner, 2013). The conceptual underpinning of Tarrant's (2010) approach (an adaptation of Values-Beliefs-Norms theory) is that sustainability courses offered abroad may promote a global citizenry by nurturing a sense of social and personal equity, pro-environmental behaviors, and civic obligations. However, these findings about the relative potency of sustainability courses taught abroad have not been previously verified using a more comprehensive measure of global outcomes and/or one that has been broadly recognized (and used) as a key indicator of global learning by institutions of higher education (such as the GPI). Moreover, there is little evidence to support the argument that studying about human-environment sustainability actually results in expanding students' global awareness, identity, and connectedness, as current thinking about the effects of studying sustainability would suggest.

\section{Hypotheses}

We hypothesize that studying abroad will be associated with more advanced global perspectives compared with traditional on-campus courses, and that this difference will be greater for courses addressing the academic arena of sustainability (such as globalization, engagement, and citizenship) than for courses unrelated to sustainability. Specifically,

1. Increments in posttest scores (from pretest) on all GPI scales (cognitive knowing, cognitive knowledge, intrapersonal identity, intrapersonal affect, interpersonal social responsibility, and interpersonal social interaction) will be significantly greater for students studying abroad than for students studying on their home campus.

2. Increments in posttest scores on all GPI scales will be significantly greater for students enrolled in sustainability courses than for students enrolled in non-sustainability courses.

3. Increments in posttest scores on all GPI scales will be significantly greater for students enrolled in sustainability courses abroad than for (a) students studying any subject on campus and (b) students at any site (on-campus or abroad) enrolled in non-sustainability courses.

4. It is further hypothesized that prior study abroad experience will have a significant positive effect, as a covariate, on the above relationships.

\section{Methods}

\section{Participants}

Undergraduate students from a large (approximately 35,000 student body) Southeastern US university were sampled in Summer 2012. Respondents had self-selected and registered for Maymester (May - June) or Summer (June - July) courses. Students were enrolled either in classes with an explicit focus on sustainability, or else in classes that had no sustainability component in their curricula. Thus students were nested in one of four groups: (1) study abroad/sustainability, (2) study abroad/nonsustainability, (3) home campus/sustainability, or (4) home campus/non-sustainability.

The study abroad/sustainability group consisted of students in a four-week education abroad Maymester program to Australia and/or New Zealand on the topic of Sustaining Human Societies and the Natural Environment. These classes included a strong experiential education component: Students spent about $75 \%$ of their time in the field and only $25 \%$ in traditional classroom lectures and seminars. The study abroad/non-sustainability group included three education abroad programs in 
Italy (focusing on fine arts), Spain (courses in Spanish language), and Argentina (courses in Latin American culture) offered during the Maymester. The study abroad/non-sustainability courses were primarily classroom-based (though students could travel in their non-structured free-time). The home campus/sustainability group was comprised of two courses (Introduction to Environmental Issues and General Ecology), both of which were offered during the Summer Semester and on campus. The home campus/non-sustainability group was composed of four courses (Introduction to Computers for Teachers; Introduction to Public Speaking; International Business; and Sociology of Gender) all offered during the Maymester and on campus. The home campus/sustainability and home campus/non-sustainability courses were entirely classroom structured.

A total of 328 respondents registered for one of the four groups of courses, of which 291 completed both the pretest and posttest instruments in a manner that permitted matching across the two administrations (yielding an $88.7 \%$ rate of usable response). The following sample sizes were obtained for each of the four groups: study abroad and sustainability ( $\underline{n}=147)$, study abroad and non-sustainability $(\underline{\mathrm{n}}=48)$, home campus and sustainability $(\underline{\mathrm{n}}=41)$, and home campus and nonsustainability $(\underline{\mathrm{n}}=55)$.

Of the 291 respondents, $60.8 \%(\underline{n}=177)$ were female. This figure closely approximates the population of undergraduate students at the institution $(57.7 \%$ female). The proportion of females in the study abroad group was $65.1 \%(\underline{\mathrm{n}}=127)$, which parallels the gender breakdown for U.S. study abroad participation at the national level (64.4\% female; Institute of International Education, 2012). The gender breakdown of the sustainability classes was $61.2 \%$ female $(\underline{n}=115)$ and non-sustainability classes was $60.2 \%$ female $(\underline{\mathrm{n}}=62)$. The majority of students' class standing was Junior, $35.4 \%$ ( $\underline{\mathrm{n}}=$ 103), followed by Sophomore, 30.2\% $(\underline{\mathrm{n}}=88)$ and Senior $19.9 \%(\underline{\mathrm{n}}=58)$. A total of 38 respondents had prior study abroad experience $(\underline{n}=16$ and 22 for the non-study abroad and study abroad groups respectively).

\section{Instruments and Procedures}

A survey was administered on day one (pretest) and the final day (posttest) of each respective course. Student participation was voluntary and no course credit was awarded for completing the instrument (an alternative reading assignment was available for students not wishing to complete the survey). Surveys were anonymous, but a coding system permitted matching pretests and posttests.

The 40-item Global Perspective Inventory Study Abroad version 2011-2012 (GPI, 2012) was used, comprised of the following six subscales: Cognitive Knowing, seven items; Cognitive Knowledge, five items; Intrapersonal Identity, six items; Intrapersonal Affect, eight items; Interpersonal Social Responsibility, five items; and Interpersonal Social Interaction, seven items). Reverse (negatively) worded items were recoded, such that higher scores on each sub-scale represented a stronger global perspective. The six GPI scales exhibited acceptable internal reliabilities (alpha coefficients) for the pretest (ranging from .61 to .74) as well as the posttest (.65 to .80). Prior study abroad experience was measured by asking respondents to indicate if they had previously studied abroad on a dichotomous (yes/no) response scale.

Analysis

Data were analysed using SPSS version 20.0 (IBM Corp., 2011). The GLM Repeated Measures 
Analysis of Variance procedure was used to test the hypotheses, with prior study abroad experience as a covariate. The two between-subjects factors were (1) sustainability (versus non-sustainability) courses and (2) study abroad (versus home campus) courses; the within-subjects factor was time (pretest versus posttest). The Repeated Measures (Simple) Contrasts subcommand in GLM was used to test for a priori differences in (1) Location by Time (hypothesis one), Topic by Time (hypothesis two), and Location by Topic by Time (hypothesis three). The Simple contrast is recommended when there are only two between-subject groups, and where the interest is in comparing them to each other, rather than (for example), to the overall mean (Taylor, 2011). The covariate (hypothesis four) was past study abroad experience, coded as $0=$ no previous study abroad experience and $1=$ previous study abroad experience. A significance level of $p=.05$ (Cohen, 1988) was used throughout.

\section{Results}

Table 1 shows mean values and standard deviations for each of the six GPI scales across the four sample groups (study abroad and sustainability, study abroad and non-sustainability, home campus and sustainability, and home campus and non-sustainability) by time of testing (pretest and posttest) accounting for the effect of the covariate (prior study abroad experience). The MANOVA test (Table 2) reveals significant two-way interactions of Location (abroad/campus) X Time (pretest/posttest) for four of the six GPI scales (the exceptions being Cognitive Knowing and Interpersonal Social Interaction). The two-way interaction of Location X Topic (sustainability/non-sustainability) exerted a significant effect on two of the scales: Cognitive Knowing and Intrapersonal Affect. The interaction of Topic X Time was significant for the GPI scales Cognitive Knowing and Intrapersonal Identity. There were no significant three-way interactions for any of the six GPI scales (though Cognitive Knowing approached significance at $p=.051$ ).

Table 1. Mean Values for GPI Scales by Location (Study Abroad versus Home Campus), Class Topic (Sustainability versus NonSustainability), and Time (Pretest and Posttest) Adjusted for Covariate (Prior Study Abroad Experience)

\begin{tabular}{|c|c|c|c|c|c|c|c|c|}
\hline & \multicolumn{2}{|c|}{$\begin{array}{l}\text { Study Abroad } \\
\text { Sustainability }\end{array}$} & \multicolumn{2}{|c|}{$\begin{array}{l}\text { Study Abroad } \\
\text { Non-Sustainability }\end{array}$} & \multicolumn{2}{|c|}{$\begin{array}{l}\text { Home Campus } \\
\text { Sustainability }\end{array}$} & \multicolumn{2}{|c|}{$\begin{array}{l}\text { Home Campus } \\
\text { Non-Sustainability }\end{array}$} \\
\hline & $M$ & $S D$ & $M$ & $S D$ & $M$ & $S D$ & $M$ & $S D$ \\
\hline \multicolumn{9}{|l|}{ Cognitive } \\
\hline $\begin{array}{l}\text { Knowing } \\
\text { Pretest }\end{array}$ & 3.76 & 0.51 & 3.70 & 0.53 & 3.38 & 0.61 & 3.73 & 0.58 \\
\hline \multicolumn{9}{|l|}{ Cognitive } \\
\hline $\begin{array}{l}\text { Knowing } \\
\text { Posttest }\end{array}$ & 3.84 & 0.49 & 3.69 & 0.58 & 3.41 & 0.65 & 3.56 & 0.63 \\
\hline \multicolumn{9}{|l|}{ Cognitive } \\
\hline $\begin{array}{l}\text { Knowledge } \\
\text { Pretest }\end{array}$ & 3.48 & 0.62 & 3.60 & 0.53 & 3.48 & 0.71 & 3.44 & 0.68 \\
\hline \multicolumn{9}{|l|}{ Cognitive } \\
\hline $\begin{array}{l}\text { Knowledge } \\
\text { Posttest }\end{array}$ & 3.86 & 0.60 & 3.82 & 0.51 & 3.48 & 0.77 & 3.58 & 0.66 \\
\hline $\begin{array}{l}\text { Intrapersonal } \\
\text { Identity } \\
\text { Pretest }\end{array}$ & 4.05 & 0.51 & 4.09 & 0.45 & 3.97 & 0.68 & 4.17 & 0.58 \\
\hline Intrapersonal & & & & & & & & \\
\hline $\begin{array}{l}\text { Identity } \\
\text { Posttest }\end{array}$ & 4.34 & 0.44 & 4.20 & 0.40 & 4.07 & 0.57 & 4.19 & 0.55 \\
\hline
\end{tabular}




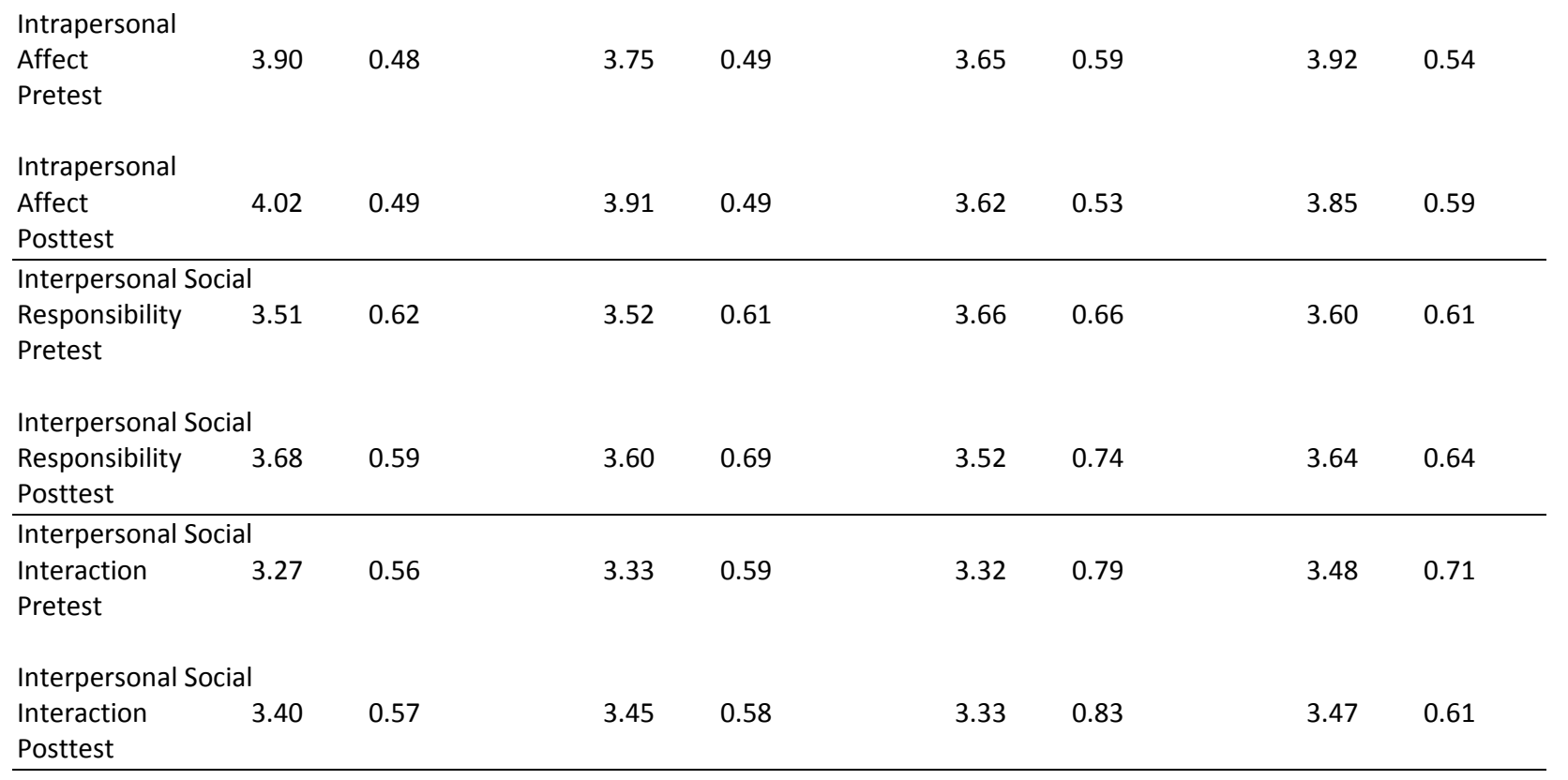

Table 2. Repeated MANOVAs for GPI Scales by Location (Study Abroad versus Home Campus), Class Topic (Sustainability versus Non-Sustainability), and Time (Pretest and Posttest) with Covariate (Prior Study Abroad Experience)

\begin{tabular}{|c|c|c|c|c|c|c|c|c|c|c|c|c|c|c|}
\hline & $\begin{array}{l}\text { Location } \\
\text { F }\end{array}$ & $p$ & $\begin{array}{c}\text { Topic } \\
\text { F }\end{array}$ & $p$ & $\begin{array}{c}\text { Time } \\
\text { F }\end{array}$ & $p$ & $\begin{array}{c}\text { Location } \\
\text { by Topic } \\
\text { F }\end{array}$ & $p$ & $\begin{array}{l}\text { Location } \\
\text { by Time } \\
\text { F }\end{array}$ & $p$ & $\begin{array}{c}\text { Topic } \\
\text { By Time } \\
\text { F }\end{array}$ & $p$ & $\begin{array}{c}\text { Location } \\
\text { by Topic } \\
\text { by Time } \\
\text { F }\end{array}$ & $p$ \\
\hline $\begin{array}{c}\text { Cog. } \\
\text { Knowing } \\
(1,271) \\
\end{array}$ & 11.13 & $<0.01$ & 0.86 & 0.35 & 0.76 & 0.38 & 6.61 & 0.01 & 3.62 & 0.06 & 6.32 & 0.01 & 0.68 & 0.41 \\
\hline $\begin{array}{c}\text { Cog. } \\
\text { Knowledge } \\
(1,276)\end{array}$ & 7.33 & 0.01 & 0.01 & 0.96 & 0.09 & 0.76 & 0.01 & 0.91 & 8.62 & 0.01 & 0.01 & 0.99 & 3.83 & 0.05 \\
\hline $\begin{array}{c}\text { Intrapers. } \\
\text { Identity } \\
(1,270)\end{array}$ & 1.29 & 0.26 & 0.52 & 0.47 & 0.03 & 0.96 & 2.59 & 0.11 & 5.15 & 0.02 & 4.59 & 0.03 & 0.94 & 0.33 \\
\hline $\begin{array}{c}\text { Intrapers } \\
\text { Affect } \\
(1,269) \\
\end{array}$ & 4.24 & 0.04 & 0.59 & 0.44 & 0.04 & 0.84 & 8.51 & 0.01 & 12.53 & $<0.01$ & 0.01 & 0.91 & 0.60 & 0.44 \\
\hline $\begin{array}{c}\text { Interpers. } \\
\text { Social Resp. } \\
(1,270)\end{array}$ & 0.85 & 0.77 & 0.04 & 0.84 & 0.30 & 0.59 & 0.18 & 0.67 & 5.76 & 0.02 & 0.36 & 0.55 & 3.21 & 0.07 \\
\hline $\begin{array}{c}\text { Interpers. } \\
\text { Social Inter. } \\
(1,260)\end{array}$ & 0.14 & 0.70 & 0.92 & 0.34 & 0.53 & 0.47 & 0.32 & 0.57 & 3.68 & 0.06 & $<0.01$ & 0.98 & $<0.01$ & 0.99 \\
\hline
\end{tabular}

\section{Hypothesis 1}

It was hypothesized that changes in posttest (from pretest) scores on all GPI scales would be significantly higher for students studying abroad than for students studying on their home campus. Table 2 shows a significant two-way (Location X Time) interaction for four of the six GPI scales: Cognitive Knowledge, $\mathrm{F}_{(1,276)}=8.62, \mathrm{p}=.004$, eta $^{2}=.03$; Intrapersonal Identity, $\mathrm{F}_{(1,270)}=5.15, \mathrm{p}=.024$, eta $^{2}=.02$; Intrapersonal Affect, $\mathrm{F}_{(1,269)}=12.53, p<.001$, eta ${ }^{2}=.05$; and Interpersonal Social 
Responsibility, $\mathrm{F}_{(1,270)}=5.76, p=.017$, eta $^{2}=.02$. (The remaining two GPI scales both approached significance on this interaction with $p<.06$ in both cases.) Contrasts revealed significant differences between (1) the study abroad and non-study groups for the posttest and (2) the pretest and the posttest for the study abroad group for all four significant two-way interactions (refer to table 3), as follows: Cognitive Knowledge (study abroad versus non-study groups for the posttest), $\mathrm{F}_{(1,276)}=14.05, p<.001$, eta ${ }^{2}=.05$ and Cognitive Knowledge (pretest versus posttest for the study abroad group) $\mathrm{F}_{(1,276)}=40.62, p<.001$, eta ${ }^{2}=.13$; Intrapersonal

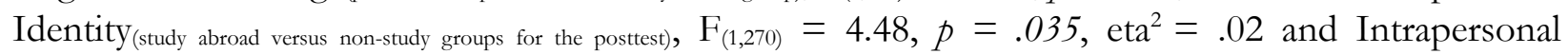
Identity (pretest versus posttest for the study abroad group), $\mathrm{F}_{(1,270)}=29.03, p<.001$, eta $^{2}=.10$; Intrapersonal Affect (study $_{\text {(n) }}$ abroad versus non-study groups for the posttest), $\mathrm{F}_{(1,269)}=10.45, p=.001$, eta $^{2}=.04$ and Intrapersonal Affect (pretest versus posttest $_{\text {(n) }}$ for the study abroad group), $\mathrm{F}_{(1,269)}=18.44, p<.001$, eta $^{2}=.06$; and Interpersonal Social Responsibility (pretest versus $_{\text {(n) }}$ posttest for the study abroad group), $\mathrm{F}_{(1,270)}=7.75, p=.006$, eta $^{2}=.03$. Collectively, results suggest that the respective GPI scales significantly increase as a result of engaging in the study abroad (versus non-study abroad) program, supporting hypothesis one.

Table 3. Mean Values and Simple Contrasts for GPI Scales by Location (Study Abroad versus Home Campus) and Time (Pretest and Posttest) Adjusted for Covariate (Prior Study Abroad Experience)

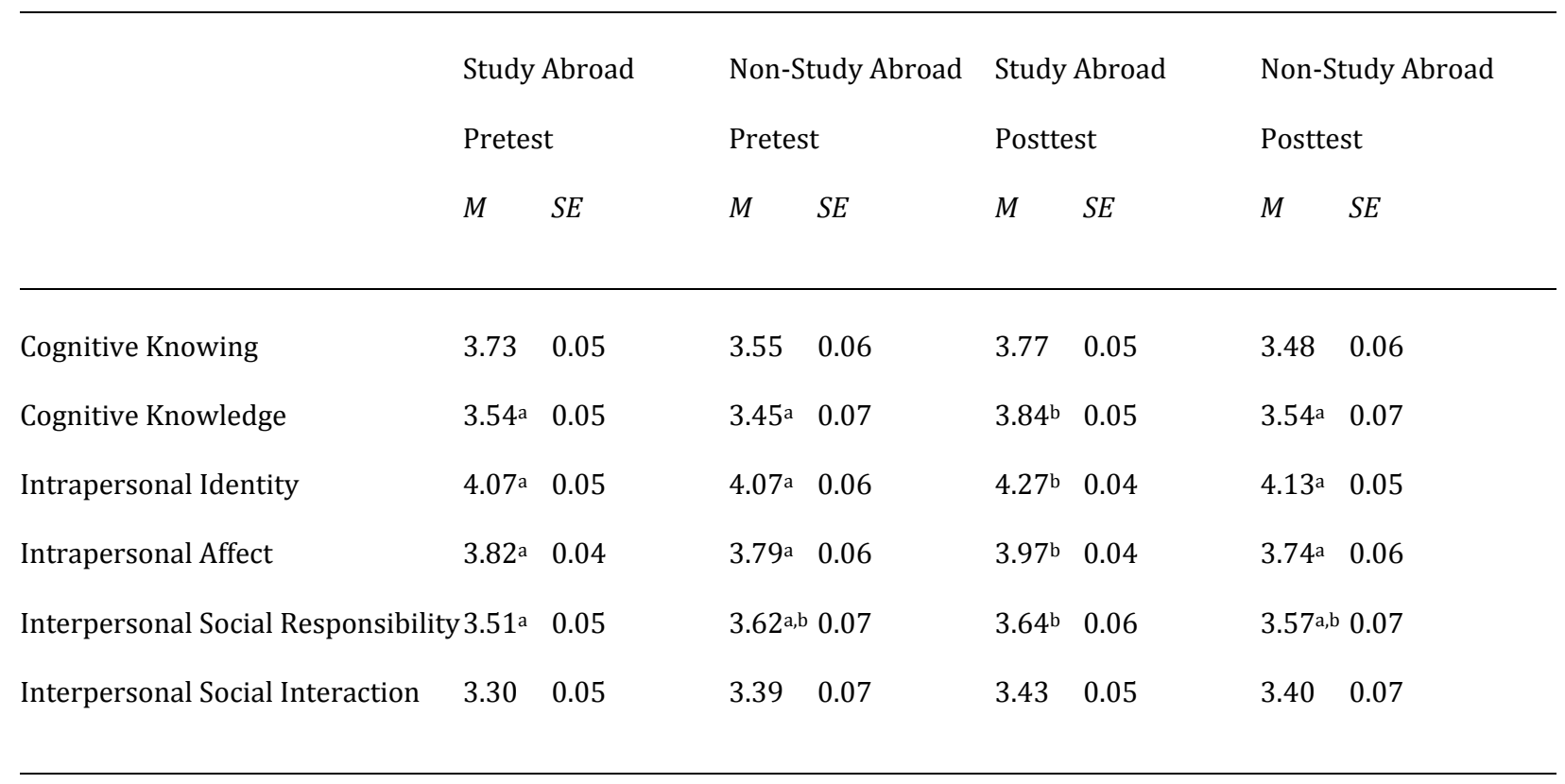

Note. Different superscripts denote significantly different mean scores at $p=.05$.

\section{Hypothesis 2}

It was hypothesized that changes in posttest scores on all GPI scales would be significantly higher for students enrolled in sustainability courses than for students enrolled in non-sustainability courses. Table 2 shows a significant two-way (Topic X Time) interaction for two of the six GPI scales: Cognitive Knowing, $\mathrm{F}_{(1,271)}=6.32, p=.012$, eta ${ }^{2}=.02$ and Intrapersonal Identity, $\mathrm{F}_{(1,270)}=4.58, p$ $=.033$ eta $^{2}=.02$. Contrasts revealed significant differences between the pretest and the posttest for the non-sustainability group for Cognitive Knowing $\left(\operatorname{mean}_{\text {(pretest) }}=3.71\right.$ and S.E.(pretest) $=.056$ and $\operatorname{mean}_{(\text {posttest })}=3.62$ and S.E.(posttest) $\left.=.058\right), \mathrm{F}_{(1,271)}=4.11, p=.044$ eta $\left.^{2}=.02\right)$. The mean values indicate 
a significant decline across time in Cognitive Knowing for non-sustainability students. For Intrapersonal Identity, a pretest to posttest gain (mean $_{\text {(pretest) }}=4.07$ and S.E.(pretest) $=.046$ and mean $_{\text {(postest) }}=4.27$ and S.E.(postest) $=.041), \mathrm{F}_{(1,270)}=25.14, p<.001$, eta $\left.^{2}=.09\right)$ was found for students enrolled in the sustainability classes only. Collectively, results offer only slight support for hypothesis two; average posttest scores were only higher on sustainability courses for one GPI scale, Intrapersonal Identity.

\section{Hypothesis 3}

Given the lack of any significant three-way interactions, hypothesis three was rejected. It could not be demonstrated from these data that students studying sustainability abroad exceeded all other student groupings on the GPI variables.

\section{Hypothesis 4}

The covariate, prior study abroad experience, was significantly and positively related to (1) Cognitive Knowledge, $\mathrm{F}_{(1,276)}=7.99, p=.005$, eta $^{2}=.03$, beta $_{\text {pretest }}=.313, \mathrm{t}=2.84, p=.005$, beta $\mathrm{p}_{\text {posttest }}$ $=.243, \mathrm{t}=2.22, p=.027$ and (2) Interpersonal Social Interaction, $\mathrm{F}_{(1,270)}=5.21, p=.023$, eta $^{2}=.02$, beta $_{\text {pretest }}=.282, \mathrm{t}=2.55, p=.011$ (beta $a_{\text {posttest }}$ was not significant). The covariate was not significantly related to any of the four remaining subscales.

Finally, significant two-way Location $\mathrm{X}$ Topic interactions emerged for two of the scales: Cognitive Knowing, $\mathrm{F}_{(1,271)}=6.61, p=.011$, eta $^{2}=.02$ and Intrapersonal Affect, $\mathrm{F}_{(1,269)}=8.51, p=.004$, eta $^{2}=.03$. However, since any such effects could not be associated with learning over time, these relationships were not of direct relevance to the purpose of the study (and therefore, the hypotheses), and consequently not explored further.

\section{Conclusions and Discussion}

Our findings offer strong support to the proposition that study abroad can promote global perspectives among college students as measured by one of the leading indicators for international education outcomes in higher education, the Global Perspectives Inventory (Braskamp, et al., 2013), beyond that achieved via on-campus courses. The specific outcomes that manifested greater increments from pretest to posttest included GPI scales Cognitive Knowing (understanding cultural relativism), Intrapersonal Identity (strong sense of personal values), Intrapersonal Affect (risk-taking), and Social Responsibility (commitment to social justice). The interactive impact of study abroad and time of testing on the two remaining GPI scales, Cognitive Knowledge (analysis of culture) and Social Interaction (intercultural social contact), just missed statistical significance $(p<.06)$.

The impact on GPI scores of taking sustainability (versus non-sustainability) courses was not convincingly demonstrated in this study (but see Tarrant, et al., 2013 for the impact of sustainability coursework on attitudes and beliefs directly pertaining to sustainability). While a pretest to posttest increment in Intrapersonal Identity scores was detected for students enrolled in sustainability courses, the significant Topic effect on Cognitive Knowing was rather due to a decrement among students enrolled in non-sustainability courses. That score, as well as the remaining four GPI scores, remained consistent from pretest to posttest for students in sustainability classes. Perhaps one reason why sustainability courses failed to manifest an advantage over non-sustainability courses in GPI scores was the particular constellation of courses that comprised the non-sustainability sample. Nonsustainability courses in this study included a class in intercultural communication and several in world 
languages, classes that themselves might be linked to student growth in global perspectives. A more dramatic advantage for sustainability classes might have emerged had the comparison group consisted of classes in, say, accounting or kinesiology laboratory methods.

A growing body of work suggests that study abroad is associated with a range of student learning outcomes, including intercultural awareness and understanding (Carlson \& Widaman, 1988; Chieffo \& Griffiths, 2004; Kehl \& Morris, 2007-2008; Litvin, 2000, 2003; Nyaupane, Teye, \& Paris, 2008; Steinberg, 2002; van 't Klooster, van Wijk, Go, \& van Rekom, 2008), personal development (Harrison, 2006; Schroth \& McCormack, 2000; Zorn, 1996), and/or functional knowledge and learning (Duke, 2000; McKeown, 2009; National Survey of Student Engagement, 2007; Vande Berg, Balkcum, Scheid, \& Whalen, 2004). Following the work of Braskamp and others (e.g., Braskamp et al., 2009; Braskamp, et al., 2012; Braskamp \& Engberg, 2011; Chickering \& Braskamp, 2009; Merrill, Braskamp, \& Braskamp, 2012; Sobania \& Braskamp, 2009), it is not surprising therefore that we found a range of global perspectives fostered more efficaciously by studying abroad than by studying on one's home campus. However, much of this previous work generally lacks stringent control groups and/or pretest/posttest measures that can empirically demonstrate the value added of studying abroad (cf., Sutton \& Rubin, 2004). The present study, in contrast, utilized an accepted quasi-experimental design (Sutton, et al., 2007), though not without certain limitations.

\section{Limitations}

As with all quasi-experimental studies, a primary limitation concerns the lack of random assignment of participants to levels of the independent variable (Campbell \& Stanley, 1963). Students self-selected/registered for courses, and thus for treatment groups, precluding true randomization of students. A number of extraneous variables probably also influenced our findings. First, the role of instructional faculty in the courses varied. Faculty not only differed between groups but also within (since groups were comprised of multiple and different courses). Second, the length of the courses differed. The sustainability/campus group completed their courses over an eight-week period while all other groups participated for only four weeks. (Yet no advantage due to this lengthier exposure emerged for this group of classes on the variables measured here.) Third, the present study treats study abroad and on-campus courses as if those were homogenous categories. Some study abroad classes are field-based and others are more classroom-based. Some involve a great deal of cultural immersion and others are more sheltered "island" programs. Future research comparing study abroad to on-campus courses would be well advised to consider key program design variables that might have explanatory power. Finally, we adopted the GPI instrument because of its stature as an increasingly accepted metric for globalization in higher education (Braskamp \& Engberg, 2011). The GPI, however, is not immune to criticism. Like many instruments built on factor analysis (see Kroger \& Wood, 1993), for example, the subscale labels tend to reify constructs that are not always reflected in the actual items comprising those subscales. At least one subsequent factor analytic study failed to confirm the "authorized” six-subscale GPI model (Samonte \& Pastor, 2011).

\section{Implications}

Given the increasing attention given by universities and colleges to preparing students to live and work in a global society, the results of this study have implications for the effect of international education on college student development and for the role of offices of international education in achieving institutional missions. While critics have argued that short-term study abroad (of less than 
eight weeks duration) may be little more than tourism opportunities with course credits attached (cf., Dwyer, 2004b; Sutton, et al., 2007), such programs now account for over 58\% of all study abroad (Institute of International Education, 2012) and, when carefully constructed and delivered, their impact on global learning outcomes should not be understated. Coupled with previous studies suggesting that any first time overseas experience fosters cognitive development (McKeown, 2009) and a Just-do-it philosophy is warranted (Tarrant \& Lyons, 2012) in international education, the profound impact of studying abroad (of even only a few weeks) on student's global perspectives extends greater than previously thought and may be far more influential than courses taught on campus (Dwyer, 2004a).

On the basis that studying abroad is associated with promoting at least four of the six GPI domains, an argument can be made that overseas education should be considered a core component of an undergraduate curriculum. Indeed, if higher education is shifting toward a more inclusive pedagogy that emphasizes how and what students think (Braskamp, et al., 2009), study abroad may provide an essential ingredient in achieving a more holistic learning experience. The AACU report (2007), College Learning for the New Global Century, for example, challenges academic institutions to consider the cumulative progress of students from school through college in developing instructional approaches that achieve four essential learning outcomes, of which a global perspective (developing a sense of personal and social responsibility) is one. The report also acknowledges the importance of preparing students with global skills and competencies identified by senior executives of US corporations as being critical for the future workforce.

What factors account for the effect of studying abroad on global perspectives? Education abroad is one factor that fosters student engagement, which in turn is linked to student achievement (Gonyea, 2008). Similarly, experiential learning in general (whether offered domestically or overseas) can transform students' perspectives through active engagement in critical learning and reflection (Kauffman, Martin, Weaver \& Weaver, 1992; Kolb, 1984; Lutterman-Aguilar \& Gingerich, 2002; McLaughlin \& Johnson, 2006; Pagano \& Roselle, 2009). Accordingly, can domestic 'study away' (from campus) programs that are academically and logistically structured similarly as short-term, overseas educational travel programs, promote similar global perspectives? Or is the international context paramount to obtaining the range and extent of global dimensions inherent in the GPI (see also, Sobania \& Braskamp 2009)? Additionally, relatively little is known about the effect of prior study abroad experience on learning outcomes associated with participating in a subsequent (second or third) overseas program. We demonstrated a significant positive covariate effect for two of the scales suggesting that past experience may positively influence learning outcomes. (However, we were unable to include prior study abroad experience as a between-subjects factor in the overall statistical model due to the limited sample size.)

Finally, study abroad is not a panacea and should not be considered as a one-size-fits-all approach for students. Certainly it is only one of several likely means for fostering student engagement (Gonyea, 2008), albeit the vehicle most directly associated with desirable global learning competencies. Only by improving our understanding of how students develop throughout their college years, and how educational programs of varying duration (short- versus longer-term) and composition (e.g., experiential, travel, homestay, etc.) influence learning outcomes, can study abroad be crafted that best match students' needs. 


\section{References}

Association of American Colleges and Universities. (2007). College learning for the new global century. Washington, D.C.: Author (www.aacu.org).

Braskamp, L. A. \& Braskamp, D. C. (2013). The globalperspectives of college students and their college experiences. Chicago, IL: Global Perspectives Institute, Inc. Retrieved from www.gpi.central.edu

Braskamp, L., Braskamp, D., \& Merrill, K. (2009). Assessing progress in global learning and development of students with education abroad experiences. Frontiers: The Interdisciplinary Journal of Study Abroad, 15, 101-118.

Braskamp, L. A., Braskamp, D. C., \& Engberg, M. (2013). The Global Perspective Inventory (GPI): Its purpose, construction, potential users, and psychometric properties. Chicago, IL: Global Perspectives Institute, Inc. Retrieved from http://gpi.central.edu/supportDocs/manual.pdf

Braskamp, L. A. \& Engberg, M. (2011). How colleges can influence the development of a global perspective. Liberal Education, Summer/Fall, 34-39.

Campbell, D. T. \& Stanley, J. C. (1963). Experimental and quasi-experimental designs for research. Chicago, IL: Rand McNally.

Carlson, J. S., \& Widaman, K. F. (1988). The effects of study abroad during college on attitudes toward other cultures. International Journal of Intercultural Relations, 12, 1-17.

Chickering, A. \& Braskamp, L. A. (2009). Developing a global perspective for personal and social responsibility. Peer Review, Fall, 27-30.

Chieffo, L. \& Griffiths, L. (2004). Large-scale assessment of student attitudes after a short-term study abroad program. Frontiers: The Interdisciplinary Journal of Study Abroad, 10, 65-77.

Childress, L. K. (2009). Internationalization plans for higher education institutions. Journal of Studies in International Education, 13(3), 289 -309.

Cohen, J. (1988). Statistical power analysis for the behavioral sciences (2nd ed.). Hillsdale, NJ: Lawrence Erlbaum Associates.

Commission on the Abraham Lincoln Study Abroad Fellowship Program. (2005). Global competence and national needs. Washington, DC: Lincoln Commission. Retrieved from http://www.aplu.org/document.doc?id=190

Duke, C. R. 2000. Study abroad learning activities: a synthesis and comparison. Journal of Marketing Education, 22, 155-165.

Durbin, R. J. (2006). The Lincoln Commission and the Future of Study Abroad. International Educator, 15(1), 4-6.

Dwyer, M. M. (2004a). Charting the impact of studying abroad. International Educator, 13(1), 14-20.

Dwyer, M. (2004b). More is better: The impact of study abroad duration. Frontiers: The Interdisciplinary Journal of Study Abroad 10, 151-163.

Elkington, J. (1998). Cannibals with forks: The triple bottom line of $21^{\text {st }}$ century business. Stoney Creek, CT: New Society Publishers.

Engberg, M. E., \& Fox, K. (2011). Exploring the relationship between undergraduate service-learning experiences and global perspective-taking. Journal of Student Affairs Research and Practice, 48(1), 85105.

Franklin, K. (2010). Long-term career impact and professional applicability of the study abroad experience. Frontiers: The Interdisciplinary Journal of Study Abroad, 19, 169-190.

Global Perspective Institute Inc. (2012). Global Perspective Inventory. Retrieved from http://gpi.central.edu

Gonyea, R. M. (2008, November). The impact of study abroad on senior year engagement. Paper presented at the Annual Meeting of the Association for the Study of Higher Education, Jacksonville, FL. Retrieved from http://cpr.iub.edu/uploads/Gonyea_StudyAbroad.pdf 
Government Accountability Office. (2007). Global competitiveness: Implications for the nation's higher education system. Retrieved from www.gao.gov/new.items/d07135sp.pdf

Hanson, L. (2010). Global citizenship, global health, and the internationalization of curriculum: A study of transformative potential. Journal of Studies in International Education, 14(1), 70-88.

Harrison, J. K. (2006). The relationship between international study tour effects and the personality variables of self-monitoring and core self-evaluations. Frontiers: The Interdisciplinary Journal of Study Abroad, 13, 1-22.

Hovland, K. (2009). Global learning: What is it? Who is responsible for it? Peer Review, Fall, 4-7.

IBM Corp. (2011). IBM SPSS Statistics for Windows, Version 20.0. Armonk, NY: IBM Corp.

Institute of International Education (2012). Open Doors Report. Retrieved from http://www.iie.org/en/Research-and-Publications/Open-Doors

Kaufmann, N. L., Martin, J. N., Weaver, H. D., \& Weaver, J. (1992). Students abroad: Strangers at home. Yarmouth, ME: Intercultural Press.

Kehl, K. \& Morris, J. (2007-2008). Differences in global-mindedness between short-term and semester-long study abroad participants at selected private universities. Frontiers: The Interdisciplinary Journal of Study Abroad, 15, 67-79.

Kolb, D. A. (1984). Experiential learning: Experience as the source of learning and development. Englewood Cliffs: Prentice Hall.

Kroger, R. O., \& Wood, L. A. (1993). Reification, "faking," and the Big Five. American Psychologist, 48(12), 1297-1298.

Lewin, R. (2009). Transforming the study abroad experience into a collective priority. Peer Review, Fall, 8-11.

Litvin, S. (2000). Revisiting 'Tourism and Understanding.' Annals of Tourism Research, 27, 526-529.

Litvin, S. (2003). Tourism and understanding: The MBA Study Mission. Annals of Tourism Research, 30, 77-93.

Lutterman-Aguilar, A. \& Gingerich, O. (2002). Experiential pedagogy for study abroad: Educating for global citizenship. Frontiers: The Interdisciplinary Journal of Study Abroad, 8, 41-82.

McKeown, J. S. (2009). The first time effect: The impact of study abroad on college student intellectual development. Albany, NY: State University of New York Press.

McLaughlin, J. S. \& Johnson, D. K. (2006). Assessing the field course experiential learning model: Transforming collegiate short-term study abroad experiences into rich learning environments. Frontiers: The Interdisciplinary Journal of Study Abroad, 13, 65-85.

McLeod, M. \& Wainwright, P. (2009). Researching the study abroad experience. Journal of Studies in International Education, 13(1), 66-71.

Merrill, K. C., Braskamp, D. C., \& Braskamp, L. A. (2012). Assessing individuals' global perspective. Journal of College Student Development, 53(2), 356-360.

Musil, C. M. (2006). Assessing global learning: Matching good intentions with good practice. Washington, DC: Association of American Colleges and Universities. Retrieved from http://www.aacu.org/SharedFutures/documents/Global_Learning.pdf

National Survey of Student Engagement. (2007). Experiences that matter: Enhancing student learning and success. Bloomington, IN: Indiana University. Retrieved from http://nsse.iub.edu/NSSE_2007_Annual_Report/docs/withhold/NSSE_2007_Annual_Report . $\mathrm{pdf}$

The National Task Force on Civic Learning and Democratic Engagement. (2012). A crucible moment: College learning and democracy's future. Washington, DC: Association of American Colleges and Universities.

Norris, E. M. \& Gillespie, J. (2009). How study abroad shapes global careers: Evidence from the 
United States. Journal of Studies in International Education, 13(3), 382 -397.

Nyaupane, G. P., Teye, V., \& Paris, S. (2008). Innocents abroad: Attitude change toward hosts. Annals of Tourism Research, 35, 650-667.

Pagano, M. \& Roselle, L. (2009). Beyond reflection through an academic lens: Refraction and international experiential education. Frontiers: The Interdisciplinary Journal of Study Abroad, 18, $217-$ 229.

Paige, R. M., Fry, G. W., Stallman, E., Jon, J-E., \& Josić, J. (2010). Beyond Immediate Impact: Study Abroad for Global Engagement (SAGE). Report Submitted to the Title VI: International Research and Studies Program U.S. Department of Education. Retrieved from https://csu.net/engage/documents/study-abroad-for-global-engagement.pdf

Samonte, K., \& Pastor, D. (2011). An exploratory factor analysis of the Global Perspectives Inventory. Paper presented at the $23^{\text {rd }}$ Annual Convention of the Association for Psychological Sciences, Washington, DC. Retrieved from http://www.psyc.jmu.edu/assessment/research/pdfs/The\%20Global\%20Perspective\%20Inve ntory FINAL.pdf

Schroth, M. L. \& McCormack, W. A. (2000). Sensation seeking and need for achievement among study abroad students. The Journal of Social Psychology, 140, 533-535.

Sobania, N. \& Braskamp, L. A. (2009). Study abroad or study away. Peer Review, Fall, 23-26.

Stearns, P. N. (2009). Educating global citizens in colleges and universities: Challenges and opportunities. New York, NY: Routledge.

Steinberg, M. (2002). Involve me and I will understand: Academic quality in experiential programs. Frontiers: The Interdisciplinary Journal of Study Abroad, 8, 207-229.

Streitwiser, B. \& Light, G. (2010). University students and conceptions of global citizenship: A case study. Northwestern University, Evanston, IL: The Center for Global Engagement. Retrieved from www.cics.northwestern.edu/documents/workingpapers/CGE 10-001 Streitwieser_Light.pdf

Sutton, R. C., Miller, A. N, \& Rubin, D. L. (2007). Research design in assessing learning outcomes of education abroad programs. In M. Bolen (Ed.), A Guide to Outcomes Assessment in Education Abroad (pp. 23-59). Carlisle, PA: Forum on Education Abroad.

Sutton, R. C. \& Rubin, D. L. (2004). The GLOSSARI project: Initial findings from a system-wide research initiative on study abroad learning outcomes. Frontiers: The Interdisciplinary Journal of Study Abroad, 10, 65-82.

Tarrant, M. A. (2010). A conceptual framework for exploring the role of studies abroad in nurturing global citizenship. Journal of Studies in International Education, 14(5), 433-451.

Tarrant, M. A. \& Lyons, K. (2012). The effect of short-term educational travel programs on environmental citizenship. Environmental Education Research, 18, 403-416.

Tarrant, M. A., Lyons, K., Stoner, L., Kyle, G. T., Wearing, S. \& Poudyal, N. (2013). Global citizenry, educational travel, and sustainable tourism: Evidence from Australia and New Zealand. Journal of Sustainable Tourism, 22(3), 403-420.

Tarrant, M. A., Rubin, D., \& Stoner, L. (2013). The added value of study abroad: Fostering a global citizenry. Journal of Studies in International Education, 18(2), 141-161.

Taylor, A. (2011). Using the GLM procedure in SPSS. Sydney: Macquarie University. Retrieved www.google.com.au/search?client $=$ safari\&rls $=$ en $\& q=$ post + hoc + tests + for + significent + intera ctions + in + GLM + spss\&ie $=$ UTF-8\&oe $=$ UTF$\underline{8 \& g w s \text { rd=cr\&ei }=401 \mathrm{WU} \text { o6aEI3akgXcpoCIBQ }}$

Van 't Klooster, E., van Wijk, J., Go, F., \& van Rekom, J. (2008). Educational travel: The overseas internship. Annals of Tourism Research, 35(3), 690-711.

Vande Berg, M. J., Balkcum, A., Scheid, M., \& Whalen, B. J. (2004). The Georgetown University 
consortium project: A report at the halfway mark. Frontiers: The Interdisciplinary Journal of Study Abroad, 10, 101-116.

World Commission on Environment and Development (1987). Our common future. London: Oxford University Press.

Zorn, C. R. 1996. The long-term impact on nursing students of participating in international education. Journal of Professional Nursing, 12, 106-110. 